Table 1. Agen MICE

$$
\text { Appearance of }
$$

uterus

Sizes of all litters born

$$
\begin{array}{lcc} 
& \begin{array}{c}
\text { Regres- } \\
\text { sing } \\
\text { implant- }
\end{array} \text { Age } \\
\text { Normal } & \text { embryos } & \text { ations } \\
\text { emonths days }
\end{array}
$$

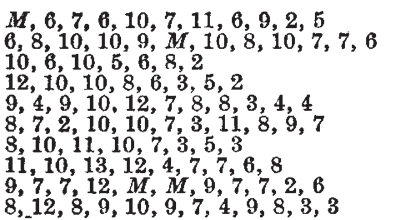

6
3
3
2
4
11
4
7
5
3

$$
\begin{array}{rr}
\mathbf{5} & \\
\mathbf{4} & \\
12 & \\
\mathbf{4} & \\
\mathbf{4} & \\
\mathbf{1} & \\
\mathbf{5} & \\
\mathbf{4} & \\
\mathbf{3} & \\
\mathbf{5} &
\end{array}
$$$$
\begin{array}{rr}
10 & 2 \\
9 & 21 \\
9 & 17 \\
9 & 11 \\
9 & 15 \\
9 & 15 \\
9 & 15 \\
10 & 18 \\
10 & 11 \\
10 & 20
\end{array}
$$

Young mice

$\begin{array}{cccc}\text { Virgin } & 7 & 0 \text { Approx. } 2 \text { months } \\ \text { ", } & 7 & 1 & , " \\ \text { ", } & 9 & 0 & ", \\ \text { M, litter mutilated by mother before it could be counted. } & 3 & 1 & \end{array}$

It will be seen that the embryonic loss in the aged mice is considerably higher than in the young mice, although the total number of implantations is not much less than the number of offspring per litter born during their early breeding life.

These results provide further direct evidence of the cause of the declining fertility in aged mice. However, they still leave open the question as to whether the failure of the implanted embryos to develop is due to structural changes in the uterus, changes in the endocrine environment or lethal factors in the eggs.

\section{A. FInN}

Department of Physiology,

Royal Veterinary College, London, N.W.1.

Bittner, J. J., Nat. Bull. No. 2, Roscoe B. Jackson Memorial Lab., $3(1936)$.

${ }^{2}$ Biggers, J. D., Finn, C. A., and McJaren, A., J. Reprod. Fert. (in the press).

${ }^{3}$ Perry, J., Embryol. Exp. Morph., 2, 308 (1954).

- Jones, E. O., and Krohn, P. L., J. Endocrinol., 21, 469 (1961).

\section{A Phosphorus-Magnesium Interaction in Tomato Nutrition}

Applications of phosphorus to an acid greenhouse soil initially low in this nutrient has resulted in increased tomato yield and reduced the incidence of manganese toxicity ${ }^{1}$. This observation has previously been noted ${ }^{2}$. Other effects accruing from phosphorus applications, however, are decreased leaf contents of nitrogen and potassium ${ }^{3}$.

In further experimental work on the acid soil referred to ${ }^{1}$ superphosphate and lime were applied at 0 and $2 \frac{1}{2}, 6$ and 0 and 10 and $20 \mathrm{oz}$. per sq. yd. respectively. Apart from the beneficial effect of both fertilizers on yield, plant growth and excess manganese symptoms it was further observed that some plants developed leaf chlorosis typical of magnesium deficiency. Soil and plant analysis confirmed this observation (Table 1).

The most notable feature of the results is that at the 'no calcium' level the available magnesium of the soil and the magnesium status of the plant decreased with increasing phosphorus application. The available soil magnesium content and plant uptake increased with rate of lime applied. While levels of available soil potassium were reduced by the phosphorus fertilizer particularly in the 'no calcium' treatment no clear-cut effect was discernible in the potassium status of the plants.

\begin{tabular}{|c|c|c|c|c|c|c|c|c|}
\hline \multirow[b]{2}{*}{ Treatment } & \multicolumn{4}{|c|}{ Soil } & \multicolumn{4}{|c|}{ Leaves } \\
\hline & $\mathrm{Ca}$ & $\stackrel{P}{\text { per a }}$ & $\underset{(\mathrm{re})^{*}}{\mathrm{~K}}$ & $\mathrm{Mg}$ & $\begin{array}{l}\mathrm{Ca} \\
\text { perc }\end{array}$ & $\begin{array}{l}\mathrm{P} \\
\text { same }\end{array}$ & $\begin{array}{l}\mathrm{K} \\
\text { ven } \\
\text { les }\end{array}$ & $\underset{\text { ried }}{\mathrm{Mg}}$ \\
\hline No $\mathrm{P}$ No $\mathrm{Ca}$ & 2,367 & $5 \cdot 5$ & 1,000 & 185 & $3 \cdot 6$ & 0.08 & $5 \cdot 5$ & 0.70 \\
\hline Med. P No Ca & 2,400 & $10 \cdot 67$ & 978 & 170 & $2 \cdot 9$ & 0.08 & $6 \cdot 9$ & 0.47 \\
\hline High $\mathrm{P}$ No Ca & 3,833 & $19 \cdot 67$ & 754 & 120 & $3 \cdot 7$ & $0 \cdot 16$ & 5 & 0.36 \\
\hline No P Med. Ca & 2,333 & $4 \cdot 5$ & 972 & 215 & $2 \cdot 7$ & 0.06 & 5 . & 0.77 \\
\hline Med. P Med. Ca & 2,633 & 11.83 & 976 & 235 & 2 . & 0.0 & & 0.86 \\
\hline High P Med. Ca & 4,233 & $24 \cdot 67$ & 856 & 215 & $2 \cdot 9$ & 0.14 & 6 . & 0.52 \\
\hline No P High Ca & 2,73 & $5 \cdot 33$ & 925 & 25 & $3 \cdot 1$ & 0.06 & 5 & 0.86 \\
\hline Med. P High Ca & $2 \cdot 500$ & $13 \cdot 67$ & 905 & 245 & $3 \cdot 6$ & 0.07 & 5 & 0.89 \\
\hline & 4,800 & $18 \cdot 17$ & 942 & 255 & $3 \cdot 5$ & 0.14 & $5 \cdot 2$ & 0.72 \\
\hline
\end{tabular}

Table 1. EFFeCT OF SUPERPHOSPHATE AND LIME ON AVATLable Soll Cations and Plant Uptake

While magnesium deficiency of tomatoes has been largely attributed to excess soil potassium ${ }^{4,5}$ on this particular soil there has been an interaction between available soil magnesium, plant magnesium and applied phosphorus.

Soils Division, An Foras Talúntais, Johnstown Castle, Wexford.

\section{EILIS CONROY}

\author{
J. G. D. LAMBE
}

An Foras Talúntais,

Horticultural and Forestry Division,

Kinsealy, Malahide, Co. Dublin.

${ }^{1}$ Lambe, J. G. D., Irish J. Agric. Res., 1, 17 (1961).

${ }^{2}$ Lutrick, M. C., Diss. Abstr., 16, 7311 (1956).

${ }^{3}$ Malcolm, J. L., Proc. Soil Crop Sci. Soc. Fla., 17, 219 (1957).

4 Walsh, T., and Clarke, E. T., Dep. Agric. J., 39, 316 (1942).

'Messing, J. H. L., Hobson, G. E., and Winson, G. W., A.R., Glasshouse Crops Res. Inst., 99 (1957).

\section{An Unusual Parasymbiont of Marine Lichens}

THE ascocarps of lichens vary in form from one species to another. Their development in several species has been examined by Doppelbaur ${ }^{1}$, but nothing is known of the mechanism controlling their morphology. Study of a recently identified lichen parasymbiont suggests that the thallus may have a determining role.

Deakin ${ }^{2}$ described as Sagedia marina a plant which was collected on "rocks submerged by the sea at high-water, Meadfoot, etc., near Torquay, Devonshire". It has since been found elsewhere between high-and low-water marks on the coasts of the British Isles and of Western Europe ${ }^{3,4}$. Hitherto classed as a lichen, it has usually borne the name Arthopyrenia marina (Deakin) A. L. Sm., though von Keissler transferred it to the genus Thelidium Mass. ${ }^{5}$ and (from the synonymous Verrucaria leptotera Nyl.) to Pseudarthopyrenia Keissl. ${ }^{6}$. But examination of the typo specimen in the British Museum Herbarium shows that it is in fact a parasymbiont on Verrucaria mucosa Wahlenb. - that is, a parasite which does not harm the lichen but appears to share the thallus with the lichen's own aseocarps. Authentic material of Arthopyrenia leptotera (Nyl.) Arn. named by Nylander and also in the British Museum Herbarium belongs to the same species and the name is a later synonym. Since it is a parasymbiont the species should be transferred to the genus Pharcidia Körber. This will be dealt with elsewhere; but unfortunately the combination Pharcidia marina is precluded by its applica. tion (illegitimate) by Bommer ${ }^{7}$ to the species now known as Arthopyrenia consequens (Nyl.) Arn. (syn. A. sublitoralis (Leight.) Arn.).

Material of the parasymbiont that $I$ collected in July 1961 in Ireland, West Cork (vice-county $H 3$ ), Tragumna Bay, on acidic shale shows an interesting 